\title{
THE IMPLEMENTATION OF \\ TRAINING AND DEVELOPMENT PROGRAM: A STUDY CASE AT PT BANK NEGARA INDONESIA BRANCH
}

\author{
${\text { Rosalin Ayal'; }{ }^{1} \text { Isanawikrama²; Yud Buana }}^{3}$ \\ ${ }^{1,2,3}$ Binus Entrepreneurship Cente, Management Department, Bina Nusantara University \\ Jl. Kebon Jeruk Raya No. 27, Kebon Jeruk, Jakarta 11530, Indonesia \\ ${ }^{1}$ rosalinayal@binus.ac.id; 2isanawikrama@binus.ac.id; ${ }^{3}$ yudbuana@binus.ac.id
}

\begin{abstract}
This research discussed the implementation of training and development programs in an organization. Undertaken deep interview as a method, it was reviewing the training and development programs of PT Bank Negara Indonesia Cabang Pasar Klewer di Surakarta (BNI CPKS) that covered the nature of training and development programs, training and development process, and behavioral aspects of the process. This research used the qualitative approach, consisted of literature theories and previous researches also explored analysis from the author by deep interview to 15 employees including management level of existing company's unit/ departments. The analysis was undertaken through collecting data first, presenting the training and development programs and then comparing them with the relevant theories. By having a well-implemented training and development programs, it was hoped that the effort would result from the accomplishment of short-term, midterm, and long-term goals of the company. As the conclusion, the work of training and development programs at $B N I$ CPKS in overall is considered poor. The Human Resource Management, which is under administration level has no right to run its main responsibilities, which are to coordinate and arrange company's training and development programs. Almost process of training and development program is set by central (Jakarta) or regional (Semarang) office. In addition, the behavioral aspect negatively affects to the training and development programs of BNI CPKS, inducing all management levels to participate the training and developments programs as a formality.
\end{abstract}

Keywords: implementation, training and development, training program, development program

\section{INTRODUCTION}

In general, training and development is a planned and systematic effort to modify or develop knowledge/skill/attitude through learning experience to achieve effective performance in an activity or range of activities (Buckley \& Caple, 2009). It is important tools for the quality of organization's performance and should be planned, formulated, and implemented not only by management but also by employees. Effective management of the acquisition and training of human capital is thus an important key to organizational success (Salas et al., 2012). Management can use it as an input to improve their training and development program. For the employees, they will be more realizing the importance of training for their self. And for the future research, which it can be used as the reference to do other researches related to training and development program. The general benefits received from employee training are increased job satisfaction and morale, increased motivation, increased efficiencies in processes, resulting in the financial gain, increased capacity to adopt new technologies and methods, increased innovation in strategies and products and reduced employee turnover (Elnaga \& Imran, 2013). 
A perfect employee training and development program must be the mixture of knowledge, career development, and goal setting (Jehanzeb \& Bashir, 2013). The major goal of training and development program is providing an employee with skills and knowledge that can be used immediately on the job or in the future. Then, benefits of training and development would be arise include improved organizational performance (e.g., profitability, effectiveness, productivity, operating revenue per employee), as well as other outcomes that relate directly (e.g., reduced costs, improved quality and quantity), or indirectly (e.g., employee turnover, organization's reputation, social capital) to performance (Aguinis \& Kraiger, 2009). Demand for employee increase, skill to cope with those demands must be found, and many companies invest heavily in helping the employee to do this through development and learning activities/training. Training opportunities may, therefore, serve a general purpose in making the employees feel important and taken care of, in terms of having opportunities to develop (Dysvik \& Kuvaas, 2008). Many companies invest in the systematic program to develop employees at each level of their careers. Therefore companies' structure developmental experiences through which employees can acquire necessary skill are these include job assignments, task forces, and job rotation (Kuvaas \& Dysvik, 2009). The terms of training and development refer to the total structure of on-the-job and off-the-job programs by organizations in developing job performance and career advancement (Bertolino, Truxillo, \& Fraccaroli, 2011).

There are some examples of skill dimensions in training and development program (Aguinis \& Kraiger, 2009); administrative (planning, developing systems; working efficiency), communication (speaking and writing effectively, listening, making presentations), interpersonal (building relationship, managing disagreement), motivation (drive for results, showing work commitment), organizational knowledge (technical expertise, ability to use financial data), self-management (acting with integrity, self-development). Another recommendation for using training is to make arrangements that as soon as the individual returns from the training experience that they are required teach the main points, key concepts, and critical techniques to a group of colleagues (Kuvaas, Buch, \& Dysvik, 2012). Sharing the learning experience maximizes the investment that the organization makes in the individual.

Reformation era in Indonesia makes competitiveness among banks increases. Each bank wants to attract customer as much as possible to make them survive. And as mentioned, competency of the employee is one of many important factors to make it (Buchori, Ibrahim, \& Saman, 2016). Then, in this case, training and development program become priority investment. Generally, training and development come up because of some organizational internal and external factors such as staff turnover, technology changes, job role changes, the new procedure, market pressures, government regulations, performance variations, and equality or opportunity (Dysvik \& Kuvaas, 2008).

BNI CPKS is one of development branch banks in Surakarta. The establishing of PT Bank Negara Indonesia (Persero) has a big part in the birth of Republic Indonesia. Republic Indonesia's Ministry meeting on September 19, 1945, decided to establish a state bank with a function as a circulation bank. Then, Bank Negara Indonesia has changed the function as a public bank to help national economic development. On August 17, 1965, Bank Negara Indonesia changed its name again to Bank Negara Indonesia Unit III based on the Penetapan Presiden 1965 No. 17 about government banks integration. In 1967, all government banks reversed to the previous function before the integration. Next, with the constitution 1968 No. 17, Bank Negara Indonesia Unit III change name to Bank Negara Indonesia 1946 with the function as a Bank Umum Milik Negara. It directs its activities to the betterment and welfare of the people and for the development of the national economy, with emphasis on the industrial manufacturing sector. PT Bank Negara Indonesia (Persero) has active participation in the national development that is evidence of its dual role. Firstly, as a governmentowned bank that has the duty of supporting the government's policies and activities in the economy, development, monetary and banking and secondly, as a commercial company that has to make the profit to ensure its business contribution. BNI CPKS is one BNI branches that are planning to get a new larger budding in the center of the city and hiring some new peoples to work. Because training 
grows out of the belief that, with proper training and development programs; the employee could develop the skills necessary to do their job, so this is the organizations' task to have training and development as better as their competence people in the organization (Khan \& Khan, 2011).

Previous research has studied that service quality has the deep role in customer commitment forming, while commitment is dominant variable in increasing customer satisfaction (Agung, 2006). It has also stated that to increase customer commitment; the company should develop the quality of services by training. The research stop on these objectives and this research continue to discuss the implementation of training and development on Bank industry. So, for those reasons, the objectives of this study are: (1) what are company's training and development programs? (2) What role does PT Bank Negara Indonesia (BNI) play in developing the concept of training and development program? (3) What are the implications of training and development program to the employees? The expected benefit of this research is this will contribute some benefit to management, employees, and people who do the future research on this topic.

\section{METHODS}

This research has used the qualitative approach to research questions as a guided interview. It is conducted by in-depth interview or face to face of employees and Human Resource management in the company for one and a half month. The respondents are consist of 15 staffs including management level, from 5 (five) department units at BNI CPKS, two staff and one supervisor of each. The analysis consists of explanation from the researchers based on theories and data from the company by exploring BNI CPKS training and development programs implementation, comparing it with the theories and previous research. The explanations consist of (1) the literature includes theories and previous researches about training and development programs. This literature is used as basis tools to see the implementation of training and development program in practice. (2) Exploration and analysis from the researchers about the existing training and development programs in the target company.

The explanations would be collected from preliminary study and study proper. The primary source is data collection will be conducted by an exploratory study in the library and internet in order to get the literature review and theoretical background related to the research. Study proper is conducted accurate information about training and development programs from the company by indepth interview; Human Resource audit, processes, and interaction that deserve more attention in order to understand the company policy related to company's training and development programs to acquire necessary information related to the research.

\section{RESULTS AND DISCUSSIONS}

Training and development program as stated in the background is providing the trainee with skill and knowledge. Rather organizations' Human Resources Management expect to develop a process that will enable them to have the right numbers of people in the right place and the right time to perform the job. The companies aim at gaining the competitive advantage by realized the importance of training in improving the employee's performance (Elnaga \& Imran, 2013). In addition, training and development for BNI become important too because the demand of bank experts increase and competition becomes tight among banks. In Indonesia moreover, there are many critical customers in these days. In BNI CPKS itself, almost all the training and development program come from the central (Jakarta) or regional (Semarang) office. The process of delivering training and development 
until evaluation stage is set by the central or regional office, and just some part of the stages that is decided by BNI CPKS.

The result of the analysis is divided into three stages; they are assessment stage, training stage, and evaluation stage. Assessment stage is decided by the central or regional office. If the company decides to purchase a training program from a consultant or vendor and if the company decides to build program itself, it will determine by the central or regional office. But formally, BNI CPKS gets the letter from the central or regional office to clearly describing what training or development program is necessary for them. This training is necessary needed because BNI CPKS had bad evaluation result from the central office in this picked up telephone behavior. The evaluation is done through mystery shopper who makes a phone call to BNI CPKS. The mystery shopper is someone from the central or regional office (someone who assigned to do it) who make the phone call to know how the employee picks up the telephone.

The training stage is all training and development programs in BNI CPKS for staff or management level that is expected after completing the program those participants can improve their managerial, technical capabilities and their banking business visions through knowledge and understanding on vision, organization, individual leadership and system and business pattern of BNI. The examples of the existing training program are vision, mission, and strategic of BNI; work culture; and P3B (Program Pengembangan Pegawai Bankl The bank employee development program). Besides that, it is expected that the employees have an active role in implementing the managerial pattern in banking strategic fields through mastering visions and missions, the operational leadership of BNI, and advanced knowledge on management, business pattern and basic banking operation in any SBU. The examples of the existing training program are bank technology and BCM (Branch Credit Management).

The next expected result from the training is able to realize strategic leadership principles in their functions as the role models and to especially strengthen their professionalism commitment in making strategic decisions in their units parallel with organizational ethics, values, and missions. The examples of the existing training program are leadership skill, and CCRM (Corporate Correspondence Relationship Manager). Able to understand visionary leadership concepts to improve macro strategic vision so that they can improve own analytic, conceptual, and integrated thinking capabilities on the development of various regional and global factors are also the expected result from the training. The examples existing training program are the corporate vision, and company's value creation focus on performance improvement. The important training BNI CPKS ever had is P3B (Program Pengembangan Pegawai Bank/The bank employee development program) includes how employees have a certain attitude in doing their job even among them or to the customers.

The last stage is the evaluation stage that is decided by the central or regional office, which set the training program. Since the evaluation criteria are set by the central or regional office, BNI CPKS just received the result without the criteria. Furthermore, sometimes central or regional office directly interviews the trainee when the results show bad mark; why it could happen, what are the difficulties, and so on without sent both of the criteria and the result to BNI CPKS. Once a month, BNI CPKS has a meeting to socialize new training that already done during that month. All employees come to that meeting; listen to the employee who received new training which explains what he/she is learned. According to the findings of research and theory at the literature review, it can be set the training and development model at BNI CPKS in Figure 1.

Even though the branch has the same mission and vision with the central or regional office, does not mean that all strategies including training and development program just received from the central or regional office. Every place has different situation and condition, which will affect corporate strategy, and who know better the condition is who live there. It is necessary to identify whether the training and development program align with and support the strategies of the BNI CPKS. It is 
important for the organization to decide their own training and development requirements including the format and design to be implemented. The same is true with the training and development principal that has functioned to transfer knowledge, skill, and attitude based on the desire of organization.

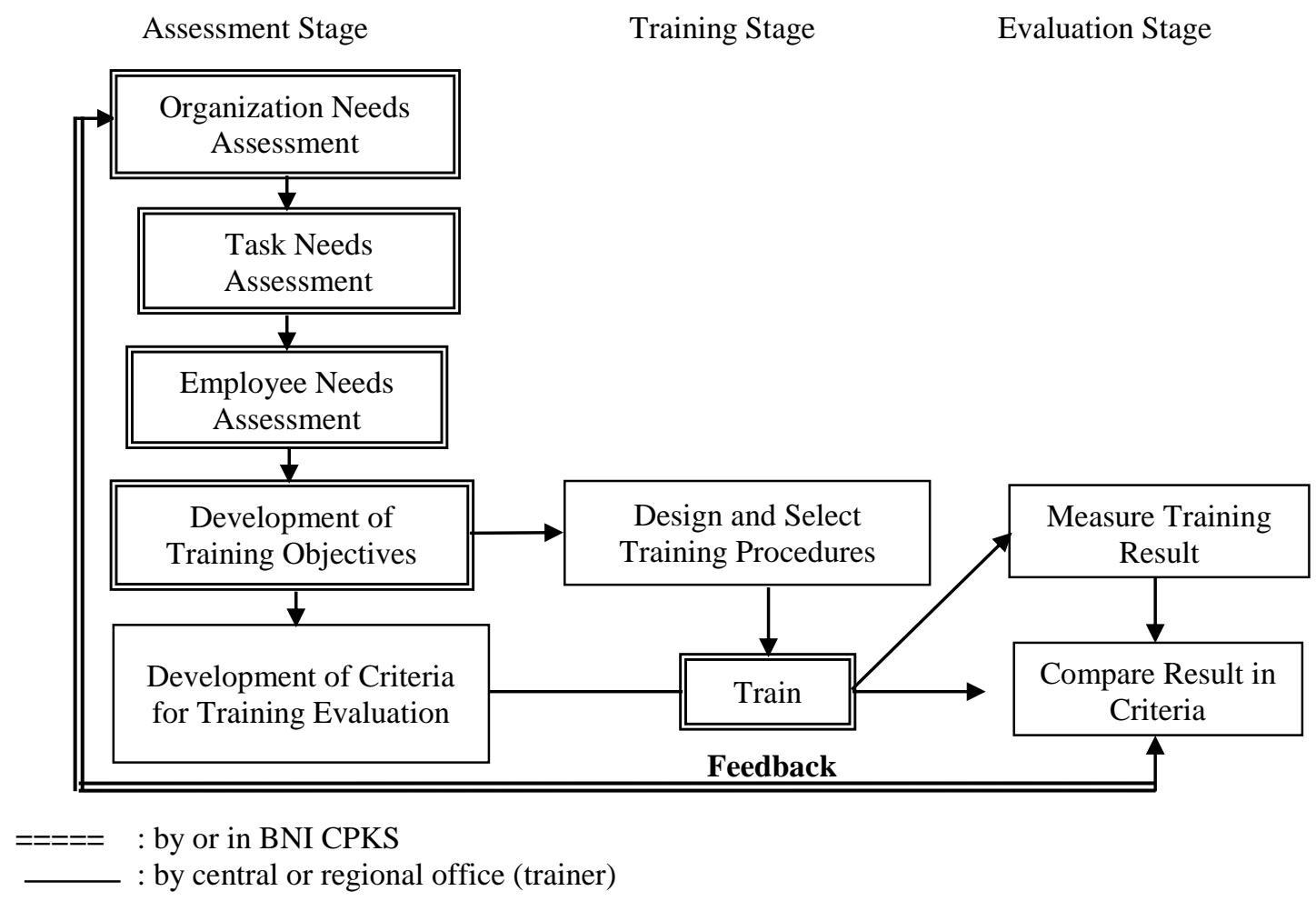

Figure 1 Model of BNI CPKS Training and Development Process

One of many ways to assess what the training and development needed by the company is the interview with the employee or a team to describe what issues have been developing in the organization. Some information such as the description of problems, when and how problems happen, can be gathered from that interview. In other words, the managers diagnose all present problems on future challenges, which will be met through training and development. After training complete, the certain participants receive a great deal of new knowledge. But what appeared to be more critical of them are their new found abilities to access knowledge and to utilize it in order to attempt in solving the problems that they faced on a daily basis. They appear to have acquired a wide repertoire of skills, yet skills development is no an active component of the program. These situations make almost all employees are unmotivated to use the training programs knowledge and skills mastered on the job. Moreover, there are job rotations continuously in BNI CPKS that make employees' increased involvement in all aspect of the business. Employees' satisfaction and motivation may be adversely affected because they find it difficult to develop functional specialties and they do not spend enough time in one position to receive a challenging assignment that is why development is becoming more important for all employees.

There are many ways to set employee development program, for example is performance appraisal system to training programs. These include ranking employees, rating their work behaviours, rating the extent to which employees have desirable traits believed to be necessary for job success and directly measuring the results of work performance after training. These approaches can be useful for employee development under certain conditions. The appraisal system to training programs must give employees specific information about their performance problems and ways to improve their 
performance. This includes providing a clear understanding of the differences between current performance and expected performance after training, identifying the causes of the performance discrepancy, and developing action plans to improve performance. That is why key aspect of training design is formulating a training program that directly addresses individual and organizational problems (Salas et al., 2012).

Since the criteria do not recognize the company especially the program assigned by BNI CPKS, they do not know how to evaluate their employee. So, BNI CPKS has their own training objectives to know the performance or outcome for evaluation criteria similar; bow trainee satisfaction is the reaction, how the trainee is learned - learning, and there is behavior improvement on the job or not - behavior. Through those evaluation criteria, BNI CPKS knows the performance of the employee and could be set new strategy to them, including the strategy to set training in line with the need. When the employee feels motivated, it improves their services and at the end obtaining higher customer satisfaction. Research proves that human resource has a positive and significant impact on customer satisfaction, and quality of employee is the important element of it (Sriwidodo \& Indriastuti, 2012).

Compare to the previous research, the implications of that training and development programs at BNI CPKS is this training and development programs just "something to do" for trainee because even company has some expectations, they do not give better development program to motivate them. This condition would reduce customer satisfaction. The lower the development and support, the more likely that transfer of training will not occur. One way to prepare trainees to deal with these unmotivated is to provide instruction self-management techniques at the end of the training programs. So, the limitation of this research is for next research; it should be discussed about training needs, advantages and disadvantages of the training; time management for training, trainer, place, situation, or content of training to make effective training for employees.

This unmotivated condition could be either caused by there is no team building training in BNI CPKS, which very important to refresh all people in BNI CPKS in terms of their mentality and psychics. Since almost training and development programs and daily works in BNI CPKS become routine activities, it is important to refresh their mind to motivate them in doing their job. There are some games can be used to do that. Outbound training is one example of those games. Outbound training is training program with experiential teaming in open air (alam terbuka) through games, simulations, discussions, and experiences as a material media (Buchori, Ibrahim, \& Saman, 2016). By way of straight embrace on training outbound activities, the trainee will get feedback almost immediately; therefore it can be used for personal development by each employee in the future.

Human resource results resume to training and development function regulation at BNI CPKS are (1) training is determined by the central office and branch manager does not yet include on training objective analysis to central (Jakarta) or regional (Semarang) office. Consequently, the training is often just a duty that it does not need to do for the trainee. (2) The trainee is decided by the central office with the unclear criteria; thus sometimes the advantages do not directly reflect on their performance or unit where they placed. (3) There are no employee orientation programs. The current orientation program that has been done only comes from superordinate initiative individually, and it does not have the direct link with the career development and have no integrated training map. (4) Almost programs oriented for central office precisely branch, which more need it have no attention. (5) BNI CPKS have no training and development evaluation programs that content of trainee, trainer or facilitator, even training consultant. 


\section{CONCLUSIONS}

From the data analysis it can be concluded that training and development programs at BNI CPKS are ineffective and inefficient. This is caused by (1) BNI CPKS itself does not determine almost all training and development programs. Training and development programs that have been done in BNI CPKS are operational training and development programs; such as teller, bank technology, and BNI vision, mission, and strategic. (2) In developing the concept of training and development programs, BNI CPKS plays the role as an executor of central (Jakarta) or regional (Semarang) office decision in terms of training and development programs should be followed by the employee. The implication of training and development programs at BNI CPKS for the employee is knowledge and skill improvement related to their current job. For some employees, training and development programs that are joined just duty should do and follow as an instruction. Moreover, the limitations of this research are the objectives which are related to the internal need of training only. This could be next research, to analyze the relation between effective training with customer satisfaction.

\section{REFERENCES}

Aguinis, H., \& Kraiger, K. (2009). Benefits of training and development for individuals and teams, organizations, and society. Annual Review of Psychology, 60(1), 451-474. https://doi.org/10.1146/annurev.psych.60.110707.163505.

Agung, K. H. (2006). Analisis pengaruh kualitas layanan, komitmen, dan kepercayaan terhadap loyalitas konsumen (Studi kasus pada nasabah tabungan Simpeda Bank Jateng). Retrieved from http://eprints.undip.ac.id/18047/.

Bertolino, M., Truxillo, D. M., \& Fraccaroli, F. (2011). Age as moderator of the relationship of proactive personality with training motivation, perceived career development from training, and training behavioral intentions. Journal of Organizational Behavior, 32(2), 248-263. https://doi.org/10.1002/job.670.

Buchori, S., Ibrahim, M., \& Saman, A. (2016). Pengaruh character education training melalui outbound training untuk peningkatan kejujuran dan integritas. Jurnal Psikologi Pendidikan Dan Konseling: Jurnal Kajian Psikologi Pendidikan Dan Bimbingan Konseling, 2(1), 12-19. https://doi.org/10.26858/jpkk.v2i1.2089.

Buckley, R., \& Caple, J. (2009). The theory \& practice of training. London: Kogan Page.

Dysvik, A., \& Kuvaas, B. (2008). The relationship between perceived training opportunities, work motivation and employee outcomes. International Journal of Training and Development, 12(3), 138-157. https://doi.org/10.1111/j.1468-2419.2008.00301.x.

Elnaga, A., \& Imran, A. (2013). The effect of training on employee performance. European Journal of Business and Management, 5(4), 2222-2839.

Jehanzeb, K., \& Bashir, N. A. (2013). Training and development program and its benefits to employee and organization: A conceptual study. European Journal of Business and Management, 5(2), 2222-2839. 
Khan, R. A. G., \& Khan, F. A. (2011). Impact of training and development on organizational performance. Global Journal of Management And Business Research, 11(7), 62-68. Retrieved from https://journalofbusiness.org/index.php/GJMBR/article/view/546.

Kuvaas, B., Buch, R., \& Dysvik, A. (2012). Perceived training intensity and knowledge sharing: Sharing for intrinsic and prosocial reasons. Human Resource Management, 51(2), 167-187. https://doi.org/10.1002/hrm.21464.

Kuvaas, B., \& Dysvik, A. (2009). Perceived investment in employee development, intrinsic motivation and work performance. Human Resource Management Journal, 19(3), 217-236. https://doi.org/10.1111/j.1748-8583.2009.00103.x.

Salas, E., Tannenbaum, S. I., Kraiger, K., \& Smith-Jentsch, K. A. (2012). The science of training and development in organizations. Psychological Science in the Public Interest, 13(2), 74-101. https://doi.org/10.1177/1529100612436661.

Sriwidodo, U., \& Indriastuti, R. T. (2012). Pengaruh dimensi kualitas pelayanan jasa terhadap kepuasan nasabah. Ekonomi Dan Kewirausahaan, 10(2), 164-173. 